\title{
Constructing A Legal Concept of Secondary Education Management in Indonesia
}

\author{
H. Syafa'at Anugrah Pradana* Andi Pangerang Moenta Marwati Riza Muh. Hasrul \\ Faculty of Law, Hasanuddin University, South Sulawesi, Indonesia
}

\begin{abstract}
The legal concept of secondary education management in Indonesia is divided into two parts, legal norms of secondary education decentralization and motivation for legal formation on secondary education management in Indonesia. The harmonization of two regulations creates legal norms of decentralization for secondary education management. The research is a normative legal research. It uses philosophical, statute, and conceptual approaches. The research is qualitative research based on normative or doctrinal legal methods. The results show that the all norms related to decentralization and secondary education are collected in these phases, so that the orientation of secondary education management towards the systematical and structured-concept in realizing the goals of national education, to educate the life of nation. Indonesia is a country born from the values of powerful local wisdom and culture. The phenomenon of uniformity of policies that incorporate culture as a uniform thing is wrong, so that it is appropriate to return its management to those closest to the community.
\end{abstract}

Keywords: Concept; Decentralization; Education; Secondary Education

DOI: $10.7176 / \mathrm{JLPG} / 89-22$

Publication date:September $30^{\text {th }} 2019$

\section{Introduction}

Indonesia is a constitutional State; it is based on law and justice for its citizens. ${ }^{1}$ Hence, State' power is legal power, it means required and by legal guidance, therefore the validity of power is only determined by law, as soon as the law ends, the power of the constitutional State ends and as if power is united. ${ }^{2}$ People welfare becomes a main basis for every policy-making to improve the standard of living as a constitutional right of every Indonesian citizen. ${ }^{3}$

The context of unity is different from union. ${ }^{4}$ A unity State is not composed of several States, as in a federation state, but it is a single, that there is only one State, there are no States in the State. Therefore, in a unity State there is also only one government, i.e the central government which has the highest power or authority in all fields of government. This central government at the last and highest level can decide everything in the country. ${ }^{5}$

The existence of every region in Indonesia by de jure is based on Article 18 paragraph (1) of the 1945 Constitution of the Republic of Indonesia. This article initiates the emergence of regional government in Indonesia. Furthermore, by the existence of regional government then emerge a division of government power. The division of governmental power in Indonesia is divided into 2 (two) parts, namely absolute and concurrent government affairs. Absolute government affairs are government affairs as absolute authority of the central government and in this case the President as the head of government to do central government affairs; while the concurrent government affairs are government affairs which are the authority of regional governments. The implementation of government affairs in the regions is done based on the principle of decentralization.

The State has guaranteed every citizen to obtain education in accordance with Article 31 paragraph (1) of the 1945 Constitution that every citizen has the right to education. Therefore, education is a necessity for the Indonesian people which is in line with the objectives of the Unitary State of the Republic of Indonesia which is stated in the Preamble of the 1945 Constitution to educate the life of the nation.

Education is categorized as concurrent government affair, this means that education is the authority of the regional government and they have the authority to do government affairs in accordance with article 18 paragraph (1) of the 1945 Constitution of the Republic of Indonesia that the provincial, regency, and municipal governments regulate and manage their own government affairs according to the principle of autonomy and assistance tasks.

The follow-up of the authority of central government to regional government is emphasized in Article 18A paragraph (1) of the 1945 Constitution that the relationship of authority between the central government and provincial, district and municipal governments is regulated by law and considers the specificity and diversity of

\footnotetext{
${ }^{1}$ Mietzner, M. (2010). Political conflict resolution and democratic consolidation in Indonesia: the role of the constitutional court. Journal of East Asian Studies, Vol. 10 (3): 397-424.

${ }^{2}$ Hasrul, M. (2019). Kedudukan dan Tugas Staf Ahli dalam Struktur Pemerintah Daerah. Amanna Gappa, 27(1), pp. 23-28

${ }^{3}$ Sharfudin. (2009). "Pelaksanaan Politik Hukum Pidana dalam Penegakan Hukum Pidana di Indonesia", Jurnal Hukum Pro Justitia Vol. 27

No.2, p. 177

${ }^{4}$ Busroh, A.D. (1990). Ilmu Negara. Bumi Aksara: Jakarta. pp. 64-65

${ }^{5}$ Moenta, A.P., \& Pradana, S.A. (2018). Pokok-pokok Hukum Pemerintahan Daerah. Jakarta: PT RajaGrafindo Persada. p.1
} 
the region. For this reason, the researcher needs to construct this relationship in the perspective of law concept in secondary education management in Indonesia.

\section{Legal Norms of Decentralization}

Van Apeldoorn provides a definition that a State is called a unity state if power is only held by the central government, while the provinces receive power from the central government, and the province has no independent rights, in other words the province is only an implementing tool of the central government affairs. ${ }^{1}$

Considering the legal basis of regional government in Indonesia, there has been a deformation at least eight phases until the form of regional government as today. More than half a century, the division of government phases is based on the enactment of laws governing regional government in general. Each phase of regional government has a different form and structure based on general rules determined by law.

In the first phase, related to regulations that discuss education, there are no technical rules that explain and regulate the division of government affairs related to education management. It's just that, in the 1945 Constitution (before the amendment) it is said that every citizen has the right to teaching. Then, it was also said that the Government was endeavoring and organizing a national teaching system, which was regulated by law. As well as with Indonesian culture, it has also been regulated in the 1945 Constitution which is in Chapter XIII on Education.

In the second phase, the discussion on the division of government affairs in the field of education (19481957) has begun to be technically regulated in Act No. 4 of 1950 concerning the Principles of Education and Teaching in Schools. In this Acts, education and teaching is focused on education and teaching in schools. While, the in religious schools and community education, it is not regulated in this Acts. At that time, the education and teaching was intended to shape capable human beings and democratic citizens who were responsible for the welfare of society and the nation. This goal is based on the principles contained in the Pancasila, the 1945 Constitution, and on the culture of the Indonesian people. ${ }^{2}$

In the third phase, Presidential Decree No. 19 of 1965 on the Principles of the Pancasila National Education System was published as a forum for the implementation of Presidential Decree No. 224 of 1964 on the Establishment and Duties of the State Committee for Improving the Pancawardhana Education System and Presidential Decree No. 145 of 1965 on the Name and Main Formulation of the National Education System.

In the fourth phase, issues a law that perfectly regulates on education, namely Act No. 2 of 1989 concerning the National Education System amended Act No. 14 of 1965 PRPS concerning the National Education Assembly and Act No. 19 of 1965 PNPS concerning the Principle of the Pancasila National Education System. The National Education System is an integrated whole of all educational units and activities related to one another towards the achievement of national education goals based on Pancasila and the 1945 Constitution.

In the fifth phase, concerning the guarantee of equal distribution of education, the quality as well as the relevance and efficiency of education management to face challenges in accordance with the changing demands of local, national and global life, it is necessary to update education in a planned, directed and continuous manner. For this reason, Act No. 20 of 2003 concerning the National Education System (hereinafter referred to as the National Education System Acts) was established as a refinement of Act No. 2 of 1989 concerning the National Education System which was deemed inadequate in dealing with the times.

In terms of government affairs in the field of education, it has been regulated in detail in Act No. 23 of 2014. In the appendix to this law, a matrix of concurrent governmental affairs between the central government and provincial and district/municipal governments has been presented.

There are 4 (four) sub-affairs as the working areas of the provincial government in terms of concurrent government affairs in the field of education. The first; management affairs, the central government has authority in determining the National Education Standards (SNP) and Higher Education Management. Provincial regions have the authority in terms of Secondary and Special Education Management. While, the districts/municipalities has authority in terms of Elementary and Kindergarten Education Management (Table 1).

Table 1. Educational Management Affairs

\begin{tabular}{ll}
\hline \multicolumn{1}{c}{ Unit } & \multicolumn{1}{c}{ Description } \\
\hline Central Government & $\begin{array}{l}\text { Establishment of National Education Standards (SNP) and Higher Education } \\
\text { Management }\end{array}$ \\
\hline Province & Secondary and Special Education Management \\
\hline District/Municipal & Elementary and Kindergarten Education Management \\
\hline $\begin{array}{l}\text { Source: Primary data, 2019 (edited). } \\
\text { The second; sub-affair of curriculum. The central government has the authority to establish a national }\end{array}$
\end{tabular}

\footnotetext{
${ }^{1}$ Simorangkir, B. (2000). Otonomi Atau Federalisme Dampaknya Terhadap Perekonomian. Jakarta: Pustaka Sinar Harapan dan Harian Suara Pembaruan. p. 14

${ }^{2}$ Tahamata, L.C.O., Ashri, M., Riza, M, and Salle, A. (2019). A Human Rights-Based Approach to Education: Role of Local Government, Journal of Law, Policy and Globalization, Vol 85: 132.
} 
curriculum for secondary, basic education, kindergarten education, and non-formal education. The province has the authority to establish a curriculum for local content of secondary and special education. Whereas, the districts/municipalities have the authority to establish local content curriculum for basic and kindergarten education and non-formal education (Table 2).

Table 2. Identification of curriculum affairs

\begin{tabular}{ll}
\hline \multicolumn{1}{c}{ Unit } & \multicolumn{1}{c}{ Description } \\
\hline Central Government & $\begin{array}{l}\text { Establishment of secondary, basic education, Kindergarten education, and non-formal } \\
\text { education }\end{array}$ \\
\hline Province & Establishment of curriculum for local content of secondary and special education \\
\hline District/Municipal & $\begin{array}{l}\text { Establishment of local content curriculum for basic and kindergarten education and } \\
\text { non-formal education }\end{array}$ \\
\hline
\end{tabular}

Source: Primary data, 2019 (edited).

The third; sub-affair of education permit. The central government has the authority in terms of issuing permits for Private Higher Education (PTS) organized by the community and issuance of permit to foreign education units. Furthermore, the province has the authority in terms of issuing permits for secondary education organized by the community and the issuance of permit to special education organized by the community. Whereas the districts/municipalities have the authority in terms of issuing permit for basic education organized by the community and issuance of permit to kindergarten and non-formal education (Table 3 ).

Table 3. Sub-affair of education permit

\begin{tabular}{ll}
\hline \multicolumn{1}{c}{ Unit } & \multicolumn{1}{c}{ Description } \\
\hline Central government & $\begin{array}{l}\text { Issuing permits for Private Higher Education (PTS) organized by the } \\
\text { community and issuance of permit to foreign education units }\end{array}$ \\
\hline Province & $\begin{array}{l}\text { Issuing permits for secondary education organized by the community and } \\
\text { the issuance of permit to special education organized by the community }\end{array}$ \\
\hline District/Municipal & $\begin{array}{l}\text { issuing permit for basic education organized by the community and } \\
\text { issuance of permit to kindergarten and non-formal education }\end{array}$ \\
\hline
\end{tabular}

Source: Primary data, 2019 (edited).

The fourth; sub-affair of language and literature. The central government has authority in terms of fostering Indonesian Language and Literature. Meanwhile, the Province are authorized in terms of fostering languages and literature whose speakers cross district/municipal in 1 (one) provincial area. While, the districts/municipalities have authority in terms of fostering language and literature whose speakers in the district/municipal (Table 4).

Table 4. Sub-affair of language and literature

\begin{tabular}{ll}
\hline \multicolumn{1}{c}{ Unit } & \multicolumn{1}{c}{ Description } \\
\hline Central government & Fostering Indonesian Language and Literature \\
\hline Province & $\begin{array}{l}\text { Fostering languages and literature whose speakers cross district/municipal } \\
\text { in 1 (one) provincial area }\end{array}$ \\
\hline District/Municipal & Fostering language and literature whose speakers in the district/municipal \\
\hline
\end{tabular}

Source: Primary data, 2019 (edited).

\section{Motivation for Legal Establishment}

Referring to Kelsen's theory which states that motivation is divided into 2 (two) namely direct and indirect motivations. To find legal criteria related to the decentralization characteristic of secondary education management in Indonesia, the motivation used is indirect motivation.

The researcher divides the motivation for legal norm establishment into 8 (eight) phases. The first phase, the State was still at the peak of its independence after fighting to drive out the invaders. Thus, at that time the State had not yet determined the classification of education in detail and equitably. There is only affirmation regarding the right to receive lessons from teachers. The government is still working on and implementing a national teaching system.

Why the State does not use the nomenclature of "education", but still uses "teaching"? Because at that time the orientation of the State was still focused on how to maintain the independence of the Republic of Indonesia, so the nomenclature of "teaching" was oriented towards equitable distribution of education throughout Indonesia in an emergency. While, the nomenclature of "education" is oriented towards the implementation of teaching and learning activities in normal or mediocre circumstances.

The second phase, the orientation of education has included the nomenclature of "education" as regulated in Act No. 4 of 1950 concerning the Basics of Education and Teaching in Schools. The enactment of the nomenclature "education" because in this phase the State is in normal condition, different from the conditions in the first phase. And also there are classifications of the types of education as follows: 
a. Kindergarten Education and Teaching;

b. Basic Education and Teaching;

c. Secondary Education and Teaching; and

d. Higher Education and Teaching.

However, in the second phase, the orientation of education focuses education and teaching in schools. Education and teaching in question is education and teaching that is general education. As for religious and public education, it is not yet included in the urgent category at this phase. The State is still oriented towards the goal of forming capable human beings and making citizens democratic.

The third phase, there is no change in the orientation of education, especially secondary education in Indonesia. Because this phase is still following the orientation of secondary education in the second phase, so there is no change.

The fourth phase, the nomenclature of "teaching" has been omitted, and this is an indication of education in Indonesia has been in a position of development, no longer equalization. At that time, President Sukarno gave specialization to the religions in Indonesia which led to Pancasila. Thus, the orientation of education in the fourth phase is religious orientation in accordance with the values of Pancasila as Filosofische Grondslag. ${ }^{1}$

The fifth phase, the beginning of the improvement of education regulations in Indonesia with the issuance of Act No. 2 of 1989 concerning the National Education System. In this law, it is clear that the orientation of education is how to educate the life of the nation and develop Indonesian people as a whole, namely people who have faith and devote to God Almighty and have virtuous character, have knowledge and skills, have physical and spiritual health, a steady and independent personality and the community and national responsibility.

Fair distribution of education in the fourth phase has been implemented by not providing specificity related to the placement of places to get education. What the meant here is for citizens aged 6 (six) years, entitled to attend basic education, while they aged 7 (seven) years are obliged to attend basic education or equivalent education until graduation.

The orientation forms of secondary education graduates in the fourth phase other than those described above are as follows:

a. Get graduates who have the ability to interact with the social, cultural and natural environment;

b. Having ability in the world of work; and

c. Continue to the higher education phase

General secondary education is oriented towards higher education, while vocational secondary education is oriented towards the world of work.

The sixth phase; the orientation of education especially secondary education still follows the orientation of education in the fifth phase. Thus, the sixth phase can be categorized as continuation from the fifth phase.

The seventh phase; a comprehensive change related to improving the quality and relevance and efficiency of education management in facing the times. Thus, the orientation of education in this phase has been in the decentralization of education because the education management has been synergized to the local government in line with local autonomy.

The similarity between the orientation of general and vocational secondary educations gives a sign that the position of general and vocational secondary educations is similar. Thus, the treatment of the government towards the management of general and vocational secondary educations must similar, including the implementation of zoning as occur at this time.

The eighth phase; this phase is the most up-to-date phase in secondary education management. The enactment of the material household system (material huishoudingsbegrip) in Act No. 23 of 2014 provides clarity of the division of government affairs including concurrent government affairs in the field of education.

Observing more closely at these rules, it is found that the secondary education management both general and vocational secondary educations is oriented towards uniformity of secondary education management policies. The researcher says this as indicated on table 10 that the management of secondary education which is the working area of the provincial is filling the empty workload of the provincial area, because previously the provincial was authorized in terms of coordinating education management only. So that the workload by the district/municipal areas is transferred to the provincial area by considering to alleviating the workload of the district/municipal area and focusing on managing basic and kindergarten educations. Therefore, the orientation of secondary education in the eighth phase is the orientation of education management uniformity.

\section{Conclusion}

A legal concept of secondary education management in Indonesia is based on two things, namely legal norm of decentralization and motivation of legal establishment in the level of secondary education management. The legal norm of decentralization are divided into 8 (eight) phases and each phase has its legal establishment

\footnotetext{
${ }^{1}$ Usfunan, Jimmy. Z. (2015). Pancasila as the Guidelines in the Legislation in Indonesia. Academic Research International, Vol. 6 (1): 272.
} 
motivation. All norms related to decentralization and secondary education are collected in these phases, so that the orientation of secondary education management towards the systematical and structured-concept in realizing the goals of national education, to educate the life of a nation. Indonesia is a country born from the values of very strong local wisdom and culture. The phenomenon of uniformity of policies that incorporate culture as a uniform thing is completely wrong, so that it is appropriate to return its management to those closest to the community.

\section{References}

Busroh, A.D. (1990). Ilmu Negara. Bumi Aksara: Jakarta.

Hasrul, M. (2019). Kedudukan dan Tugas Staf Ahli dalam Struktur Pemerintah Daerah. Amanna Gappa, 27(1), pp. 23-28

Mietzner, M. (2010). Political conflict resolution and democratic consolidation in Indonesia: the role of the constitutional court. Journal of East Asian Studies, Vol. 10 (3): 397-424.

Moenta, A.P., \& Pradana, S.A. (2018). Pokok-pokok Hukum Pemerintahan Daerah. Jakarta: PT RajaGrafindo Persada.

Sharfudin. (2009). "Pelaksanaan Politik Hukum Pidana dalam Penegakan Hukum Pidana di Indonesia", Jurnal Hukum Pro Justitia Vol. 27 No. 2: 177

Simorangkir, B. (2000). Otonomi Atau Federalisme Dampaknya Terhadap Perekonomian. Jakarta: Pustaka Sinar Harapan dan Harian Suara Pembaruan.

Tahamata, L.C.O., Ashri, M., Riza, M, and Salle, A. (2019). A Human Rights-Based Approach to Education: Role of Local Government, Journal of Law, Policy and Globalization, Vol 85: 132.

Usfunan, Jimmy. Z. (2015). Pancasila as the Guidelines in the Legislation in Indonesia. Academic Research International, Vol. 6 (1): 272. 